\title{
L'image des locuteurs écossais au siècle des Lumières : les points de vue de Johnson, Boswell et des orthoépistes
}

The Image of Scottish Speakers During the Enlightenment Period: the Opinions of Johnson, Boswell and the British Orthoepists

\section{Rita Ranson}

\section{(2) OpenEdition Journals}

\section{Édition électronique}

URL : https://journals.openedition.org/etudesecossaises/697

DOI : 10.4000/etudesecossaises. 697

ISSN : 1969-6337

\section{Éditeur}

UGA Éditions/Université Grenoble Alpes

\section{Édition imprimée}

Date de publication : 15 avril 2012

Pagination : 131-144

ISBN : 978-2-84310-223-3

ISSN : $1240-1439$

\section{Référence électronique}

Rita Ranson, "L'image des locuteurs écossais au siècle des Lumières : les points de vue de Johnson, Boswell et des orthoépistes », Études écossaises [En ligne], 15 | 2012, mis en ligne le 15 avril 2013, consulté le 11 avril 2023. URL : http://journals.openedition.org/etudesecossaises/697 ; DOI : https:// doi.org/10.4000/etudesecossaises.697 


\section{L'image des locuteurs écossais au siècle des Lumières : les points de vue de Johnson, Boswell et des orthoépistes}

\section{Introduction}

La seconde moitié du siècle des Lumières est considérée comme une époque majeure pour l'étude de la langue anglaise. L'objectif des linguistes ${ }^{1}$, maîtres d'élocution ${ }^{2}$, rhétoriciens, lexicographes, orthoépistes et grammairiens des Lumières est de codifier la langue anglaise. Ce but était d'ailleurs résumé par l'expression suivante : « to settle, to fix, to ascertain the language ${ }^{3}$ ». En ce qui concerne la prononciation de l'anglais, il y avait une grande demande du public qui désirait avoir accès à des ouvrages présentant un modèle de prononciation, pour ne pas dire « le modèle » de prononciation correcte. Ce modèle supposait bien entendu le choix d'une variété et c'est l'anglais de Londres et de sa région proche qui s'est vite

1. Le mot « linguiste » doit être compris ici dans le sens qu'on lui prête au XVIII ${ }^{\mathrm{e}}$ siècle et que Johnson (1755) — s'appuyant sur Milton et Addison — définit ainsi : « a man skilfull in languages »; cette définition sera reprise mot à mot par Walker (1791). D'autre part, le Oxford English Dictionary, vol. VIII, 1991 [1989], p. 992, relève une première occurrence de ce sens en 1591, citant Shakespeare. Mais ce mot peut également être compris dans le sens « a student of language; a philologist »; le $O E D$ atteste du sens de ce mot chez Wilkins dès 1641. Et les auteurs dont il va être question peuvent bien être définis comme linguistes. Buchanan par exemple, utilise le latin dans son titre; Johnson connaissait le latin et les Anciens, de même que Walker qui a publié un dictionnaire pour la prononciation des noms grecs et latins. Outre les langues classiques (latin, grec et hébreu), ces linguistes connaissaient le français, l'italien, voire l'allemand; ainsi Walker se sert de la prononciation des voyelles de ces langues pour expliquer l'articulation des voyelles anglaises.

2. Nous faisons référence ici au mot anglais « master of elocution » généralement traduit en français par «maître d'élocution » ou « maître de diction »; au XIX siècle le terme « elocutionist » sera adopté (voir OED, vol. V, 1991 [1989], p. 146). Il faut cependant garder à l'esprit que ces « elocutionists » étaient aussi auteurs d'ouvrages sur le sujet : c'est le cas de Walker.

3. Ces termes sont utilisés par Swift tout au long de sa célèbre Proposition de 1712 à Robert, comte d'Oxford; ils ont été adoptés par tous ceux qui se sont intéressés à la codification de l'anglais. 
imposé pour des raisons politiques, culturelles, et, en partie, linguistiques, pour ne pas dire esthétiques.

Si on reconnaît à présent le rôle de grandes figures comme Samuel Johnson et Robert Lowth dans la standardisation de l'écrit, en ce qui concerne la langue parlée on se tourne bien volontiers vers les travaux de ceux que l'on nomme alors « orthoépistes » et plus particulièrement ceux qui ont publié un dictionnaire de prononciation. John Walker et Thomas Sheridan demeurent à ce jour les plus célèbres d'entre eux, mais il ne faut pas oublier leurs prédécesseurs, à savoir Buchanan, Johnston, Perry, Kenrick, Spence pour les plus connus. Ce sont leurs travaux qui vont contribuer à l'élaboration d'un modèle d'anglais parlé, et qui vont d'emblée, critiquer et exclure les prononciations dites « provinciales » et par conséquent stigmatiser très particulièrement l'anglais des Irlandais et des Écossais.

On s'attachera tout d'abord à montrer l'opinion déterminante de Samuel Johnson sur le sujet, relayée par Boswell et les orthoépistes. On verra ensuite, que non seulement certains orthoépistes sont écossais, mais qu'ils sont parmi les premiers à soulever les problèmes de prononciation auxquels sont confrontés les locuteurs de leur contrée, que l'on nommait volontiers « North-Britain ». Enfin, il sera utile de commenter les solutions et conseils prodigués par l'Écossais Boswell et l'Anglais Walker pour remédier à ce qu'il faut bien considérer comme une question clé à cette époque.

\section{Le discours de Samuel Johnson sur la prononciation écossaise}

$\mathrm{Si}$, dans leurs dictionnaires de prononciation, certains orthoépistes anglais rendent un vibrant hommage au travail de Samuel Johnson (tel est le cas de Walker), chez les orthoépistes écossais on observe deux attitudes. Certains, comme Buchanan (1757) préfèrent ne pas l'évoquer, alors que Burn (1777) va reconnaître lui, toute l'autorité de Johnson pour la langue écrite: « Dr. Johnson's great Dictionary is thought to be a standard for orthography and accentuation ${ }^{4}$. " John Walker décrit Johnson comme quelqu'un : "whose large mind and just taste made him capable of enriching and adorning the language with original composition ${ }^{5} »$. Johnson est donc reconnu comme une autorité en matière de codification

4. John Burn, 1786 [1777], préface, p. A2.

5. John Walker, 1791, préface, p. iii. 
du langage ${ }^{6}$. Il apparaît ainsi naturel de compléter son travail, et de proposer une codification de la langue parlée, car comme le dit Walker en 1791 : « The importance of a consistent and regular pronunciation was too obvious to be overlooked ${ }^{7}$. »

Pour en revenir à Samuel Johnson, on sait qu'il n'était pas toujours très délicat et peu diplomate avec les Écossais; on se souviendra en particulier de sa célèbre définition du mot « oats $^{8} »$. Définition paradoxale, lorsque l'on connait les liens étroits qu'il avait avec son biographe écossais, Boswell. Celui-ci rapporte dans la biographie de Johnson une partie des commentaires de ce dernier, à propos de la prononciation écossaise. Il s'agit d'une conversation qui se déroule le 28 mars 1778 entre Samuel Johnson et Sir Alexander Macdonald. La discussion a pour sujet le monde politique et juridique. On sait que ces locuteurs constituaient un public particulièrement observé en ce qui concerne la pratique de la langue et l'élocution. Au détour de la conversation, Sir McDonald fait la remarque suivante : «I have been correcting several Scotch accents in my friend Boswell. I doubt, Sir, if any Scotchman ever attains to a perfect English pronunciation ${ }^{9}$. » Ce à quoi Johnson répond : «Why Sir, few of them do, because they do not persevere after acquiring a certain degree of it $^{10}$. » $\mathrm{Si}$ ce début de réponse est un peu sévère, la suite l'est tout autant :

But Sir, there can be no doubt that they ${ }^{11}$ may attain to a perfect English pronunciation, if they will. We find how near they come to it; and certainly, a man who conquers nineteen parts of the Scottish accent, may conquer the twentieth. But, Sir, when a man has got the better of nine tenth, he grows weary, he relaxes his diligence, he finds he has corrected his accent so far as not to be disagreeable, and he no longer desires his friends to tell him when he is wrong; nor does he choose to be told ${ }^{12}$.

Johnson use ici de deux arguments, le manque de volonté d'une part, et une certaine paresse de l'autre, qui ne laissent place à aucun doute sur sa position à ce sujet. À la décharge de Johnson, il faut cependant préciser, qu'il reconnaît bien volontiers que lui-même, s'il n'y prend garde, peut révéler ses origines provinciales en s'adressant à ses interlocuteurs;

6. Joan C. Beal, 2003, p. 84, souligne d'ailleurs que le dictionnaire de Johnson, la grammaire de Lowth et le dictionnaire de Walker constituent le grand triumvirat des guides de l'usage en matière de langage; chacun d'eux étant l'ouvrage le plus important dans leur domaine.

7. Walker, 1791, préface, p. A2.

8. "A grain, which in England is generally given to horses, but in Scotland supports the people. » Samuel Johnson, 1755, entrée pour le nom « oats ».

9. James Boswell, 1980 [1791], p. 468.

10. Boswell, 1980 [1791], p. 468-469.

11. The Scots.

12. Boswell, 1980 [1791], p. 469. 
et de conclure, que les Écossais n'y échappent point. Mais à la fin de sa longue réponse il nuance le propos : «But, Sir, little aberrations are of no disadvantage. I never catched ${ }^{13}$ Mallet in a Scotch accent; and yet Mallet, I suppose, was past five-and-twenty before he came to London ${ }^{14}$. »

À une autre occasion il confirme cette opinion à son ami Boswell, qui lui demandait alors ce qu'il pensait de la qualité de sa prononciation: « Sir, your pronunciation is not offensive. » On ne peut bien entendu, pas rendre Johnson seul responsable de la réputation désastreuse de la prononciation écossaise. Buchanan, qui publie dès 1757 ce qui est considéré comme le premier dictionnaire majeur de prononciation anglaise, et qui est lui-même écossais, dit de ses compatriotes qu'ils prononcent l'anglais " after a different and for the most part unintelligible manner ${ }^{15}$ ». La question de la prononciation écossaise — tout comme celle de la prononciation irlandaise — est soulevée dans tous les dictionnaires de prononciation de cette période. Si, dans la plupart des cas, cette prononciaton n'est pas plus stigmatisée que d'autres — les auteurs parlent alors de « provincial pronunciation », terme qui n'est certes pas flatteur, mais permet de mettre toutes les prononciations régionales sur le même plan - , il arrive parfois que des commentaires un peu sévères se glissent dans les propos des auteurs. Ainsi John Walker, dans son principe 174, et sa description de la prononciation $\mathrm{du}<\mathrm{u}>$ dans des mots comportant le suffixe $<$-ful $>$ comme « wonderful » souligne : « they are sufficient to puzzle Englishmen who reside at any distance from the capital, and to make inhabitants of Scotland and Ireland [...] not unfrequently the jest of fools ${ }^{16} \gg$.

Tous ces préjugés sur la prononciation écossaise de l'anglais feraient oublier à un public non averti, que les Écossais ont contribué, pour une grande part, au débat sur la codification de l'anglais parlé.

\section{Orthoépistes écossais et prononciation écossaise}

Parmi les orthoépistes écossais il y en a certains qui sont peu connus comme Alexander Geddes, James Douglas, John Burn, et d'autres qui le sont un peu plus, voire beaucoup plus comme James Elphinston, James Beattie, John Warden, William Scott, William Angus, William Perry, James Buchanan. Cette liste est loin d'être exhaustive. Dans son étude consa-

13. Retranscrit ainsi par Boswell. « Caught » n'est pas utilisé.

14. Boswell, 1980 [1791], p. 469.

15. James Buchanan, 1757, préface, p. xv.

16. Walker, 1791, principle 174, p. 22-23. 
crée à Geddes, Charles Jones note que certains d'entre eux souhaitaient promouvoir le modèle de la prononciation de $\operatorname{Londres}^{17}$. Mais ce n'était pas le cas de tous, même si une grande majorité, comme Angus ${ }^{18}$, s'employait à présenter des excuses pour une prononciation perçue comme fautive $^{19}$. Il faut également tenir compte du fait, ainsi que Görlach nous en informe, que dans certaines villes, en particulier Glasgow ou Édimbourg, les membres de la classe éduquée décidèrent de façon délibérée d'accepter l'anglais pour le discours formel ${ }^{20}$. Dans son dictionnaire publié en 1773, William Kenrick souligne que c'est, paradoxalement, les Écossais et les Irlandais qui abordent les premiers la question de la codification de la langue parlée :

It has been remarked as a phaenomenon in the literary world, that, while our learned fellow subjects of Scotland and Ireland are making frequent attempts to ascertain, and fix a standard to, the pronunciation of the English tongue, the natives of England themselves seem to be little anxious either for the honour or the improvement of their own language ${ }^{21}$.

Il semble d'ailleurs que ces initiatives ne soient pas sans poser quelques problèmes; et c'est encore le cas en 1800, lorsqu'Angus prend la précaution suivante : «To those, who, without examination, may object to this attempt, as being the production of a North-Britain, it may be sufficient to observe, "That it makes no innovation in English pronunciation ${ }^{22}$ ". "

Cette réaction d'Angus peut s'expliquer par la réticence des Anglais à accepter des modèles fixés par des orthoépistes venus de ce qu'on appelle " the Province ». Il suffit de se souvenir de certains propos acerbes tenus par Johnson à l'occasion de la publication du dictionnaire de l'Irlandais Thomas Sheridan : «Besides, Sir, what entitles Sheridan to fix the pronunciation of English? He has in the first place, the disadvantage of being an Irishman ${ }^{23}$. » Nul doute que Johnson eût été capable de faire le même commentaire à l'endroit d'un orthoépiste écossais. Un an plus tard, en 1773, Kenrick, n'est pas plus conciliant sur le sujet :

There seems indeed a most ridiculous absurdity in the pretensions of a native of Aberdeen or Tipperary, to teach the natives of London to speak and to read.

17. Charles Jones, 1994, p. 71.

18. William Angus, 1800, p. 4.

19. Jones, 1994, p. 71.

20. Manfred Görlach, 2001, p. 65.

21. Kenrick, 1773 , p. i.

22. Angus, 1800 , p. 4.

23. Boswell, 1980 [1791], p. 470. 
Various have been nevertheless the modest attempts of the Scots and Irish, to establish a standard of English pronunciation. That they should not have succeeded is no wonder. Man cannot teach others what they do not themselves know ${ }^{24}$.

Mais en 1775, Perry — qui est écossais — semble par contre plus indulgent sur ce point avec ses compatriotes :

Whether these gentlemen ${ }^{25}$ were sufficiently acquainted with the English language, to convey the true pronunciation of it by these or any other methods, is not my province to enquire into or determine ${ }^{26}$.

On peut, en partie, expliquer la volonté de certains Écossais à prononcer correctement l'anglais pour des motifs politiques : rappelons que l'acte de l'Union de 1707 aboutit à la création d'un parlement unique et oblige, de ce fait, les parlementaires écossais à séjourner à Londres. Comme le souligne Carol Percy, cela démontre le caractère cosmopolite de Londres et elle cite Langford qui parle de «the swarm of Scotsmen ${ }^{27}$ » Mais, accepter d'écrire ou de parler l'anglais correctement («properly») est à la fois une manière de pouvoir diffuser facilement et correctement les textes ou les opinions émanant des Écossais, ${ }^{28}$ et pour les Écossais de Londres l'assurance d'intégrer les meilleurs cercles de la bonne société de la capitale. Percy souligne cependant, qu'au milieu du XVIII ${ }^{\mathrm{e}}$ siècle, on détecte dans certaines annonces une peur des Jacobite qui exclut de facto les Écossais comme professeurs ${ }^{29}$. On se doit néanmoins de constater que de nombreux Écossais comme Boswell prennent des leçons auprès de maîtres d'élocution :

Upon another occasion I talked to him ${ }^{30}$ on this subject, having myself taken some pains to improve my pronunciation, by the aid of late Mr. Love, of Drury-lane $^{31}$ theatre, and also of old Mr. Sheridan ${ }^{32}$.

24. Kenrick, 1773, introduction, p. A-ii.

25. Perry parle ici de Buchanan et Spence.

26. Perry, 1775, p. vi.

27. Carol Percy, 2004, p. 157.

28. Görlach, 2001, p. 64.

29. Percy, 2004, p. 156.

30. «Him » désigne ici Johnson.

31. Avec cette orthographe dans l'original.

32. Boswell, 1980 [1791], p. 469. Il s'agit de James Love (1722-1774) et de Thomas Sheridan (1719-1788), orthoépiste et père de l'écrivain. Tous deux sont issus du monde du théâtre, considéré comme un modèle de bonne prononciation, en particulier en la personne de David Garrick qui sert de référence absolue en ce domaine. L'orthoépiste John Walker (1732-1807) est lui aussi un ancien acteur qui a fait partie de la troupe de David Garrick. 
Mais l'apprentissage de l'anglais ne se fait pas sans une certaine difficulté; ainsi Buchanan, dans une note de sa préface, fait la remarque suivante : "The people of North Britain seem, in general, to be almost at as great a loss for proper accent and just pronunciation as foreigners ${ }^{33}$. » Lui-même ne semble pas échapper à la règle, puisque Kenrick commente l'un de ses ouvrages en ces termes:

The English reader will very readily discover, in attempting to decipher the above passage, that the essayist must be a North-Briton, and not a native of England. Admitting however that he had been capable of giving every word its true sound, this method of disfiguring the orthography is very prejudicial to the learner; $[\ldots]^{34}$.

En dépit de nombreux travaux et efforts de la part des locuteurs écossais, le public anglais du siècle des Lumières, considère la prononciation écossaise comme disgracieuse, vulgaire, incorrecte, bref, « provinciale ». Walker définit cet adjectif ainsi : " Relating to a province; [...] not of the mother country, rude, unpolished ${ }^{35}$. » Quelles solutions vont être préconisées? C'est ce qui va être étudié grâce à Boswell et Walker.

\section{Conseils et recommandations de Boswell et Walker aux locuteurs écossais}

Dans leurs études, Lynda Mugglestone et Charles Jones citent Sylvester Douglas qui, vers 1775, rend compte de la prononciation de l'anglais telle qu'elle est utilisée par ses compatriotes; il affirme que : « [their] language has already been in a great degree refined from the provincial dross, by frequenting English company and studying the great masters of the English tongue in their writings ${ }^{36}$. » Même s'il semble donc, d'après ce témoignage, que la situation s'améliore, la prononciation écossaise n'a toujours pas les faveurs du public. Presque vingt ans plus tard, en 1791, qui est aussi la date de parution du dictionnaire de Walker, Boswell, dans

33. Buchanan, 1757, p. xv.

34. Kenrick, 1773, p. ii. L'auteur précise qu'il s'agit d'un passage tiré de The Idler de Johnson que Buchanan retranscrit dans son «Essay Towards Establishing a Standard for an Elegant and Uniform Pronunciation of the English Language; Addressed to the Two August Houses of the British Parliament.» Il a été publié en 1766 sous le titre : An Essay Towards Establishing a Standard for an Elegant and Uniform Pronunciation of the English Language throughout the British Dominions.

35. Walker, 1791, entrée pour l'adjectif «provincial». Les pages du dictionnaire ne sont pas foliotées.

36. Lynda Mugglestone, 1991, p. 101. Il s'agit du Treatise on the Provincial Dialect of Scotland, publié en 1779. 
sa biographie de Johnson se voit obligé de faire les recommandations suivantes :

$[\ldots]$ and let me give my countrymen of North-Britain an advice not to aim at absolute perfection in this respect; not to speak High English, as we were apt to call what is far removed from Scotch, but which is by no means good English, and makes "the fools who use it", truly ridiculous ${ }^{37}$.

Boswell ne préconise pas la prononciation la plus pure et il n’hésite pas à se justifier, en dépit du problème esthétique que soulève la prononciation écossaise :

A studied and factitious pronunciation, which requires perpetual attention and imposes perpetual constraint, is exceedingly disgusting. A small intermixture of provincial peculiarities may, perhaps, have an agreeable effect, as the notes of different birds concur in the harmony of the grove, and please more than if they were all exactly alike ${ }^{38}$.

On peut donc parler d'une certaine indulgence, ou même d'une certaine tolérance à l'endroit de ses compatriotes. Mais il ne faudrait pas croire pour autant, qu'il soit laxiste en la matière; en commentant la prononciation d'un compatriote il affirme :

I do not mean that we should speak as broad as a certain prosperous member of Parliament from that country ${ }^{39}$; though it has been well observed that "it has been of no small use to him"; as it rouses the attention of the House by its uncommonness ${ }^{40}$.

Bien entendu, si Boswell critique ici un peu sévèrement Henry Dundas, il ne se dérobe cependant pas pour citer deux autres de ses compatriotes comme modèles à suivre. C'est ainsi qu'il renvoie au « late Sir Gilbert Elliot $^{41}$ », mais aussi au troisième comte de Marchmont ${ }^{42}$, L'avis de Boswell est intéressant car il est homme de lettres — par conséquent cultivé — et écossais. Walker, lui est anglais, ancien acteur et maître d'élocution. Il compte parmi les orthoépistes les plus célèbres du siècle des

37. Boswell, 1980 [1791], p. 469.

38. Boswell, 1980 [1791], p. 469.

39. 1 s'agit ici de Henry Dundas, 1st Viscount Melville (1713-1787), Boswell, [1791] 1980, p. 470, note 1; Boswell le mentionne à plusieurs reprises et il précise qu'en 1754 celui-ci était : « Now, one of his Majesty's principal Secretaries of State. » Boswell, [1791] 1980, p. 188, note 2.

40. Boswell, 1980 [1791], p. 470.

41. Gilbert Elliot (1722-1777).

42. Comte de Marchmont (1708-1794). Boswell 1980 [1791], p. 470 relate une anecdote à son sujet; alors que Marchmont était un jour dans une échoppe qu'il n'avait pas l'habitude de fréquenter, le marchand le prend pour un Américain puisque il ne parle « ni anglais, ni écossais ». 
Lumières, et donne les recommandations les plus précises afin de corriger cette prononciation jugée inélégante ( $\left.\operatorname{coarse}^{43} »\right)$. D'autre part, même si le concurrent direct de Walker, Sheridan, a donné des leçons d'élocution à des élèves écossais (c'est le cas de Mr. Wedderburne ${ }^{44}$ ), s'il s'est rendu en Écosse, et a discuté de la question de la prononciation écossaise, le dictionnaire de Walker présente l'avantage d'avoir été publié après tous les autres et de bénéficier par conséquent d'une solide tradition en la matière; de plus, c'est bien le dictionnaire de Walker qui finit par s'imposer au siècle suivant, et non celui de Sheridan. Enfin, dans la rubrique nécrologique que le magazine Athenaeum lui consacre, l'auteur anonyme insiste sur les liens privilégiés de Walker avec l'Écosse. Tout d'abord, Walker est catholique, et cette appartenance religieuse lui crée moins de problèmes en Écosse qu'en Angleterre en matière d'enseignement. Il a été invité à deux reprises pour des conférences à Édimbourg; il a non seulement apprécié la courtoisie des Écossais, mais également leur curiosité intellectuelle ${ }^{45}$. En outre, Walker a été le professeur d'Alexander, fils de Boswell ${ }^{46}$. Comme nous l'avons déjà précisé, la prononciation écossaise était, l'une des plus stigmatisée de toutes; elle partageait ce triste privilège avec la prononciation irlandaise. Néanmoins il n'est pas inutile de rappeler que toute prononciation utilisée par tout locuteur britannique éloigné de plus de 60 miles de Londres est considérée comme impropre ${ }^{47}$. Jones $^{48}$ relève que l'Écossais James Beattie ${ }^{49}$ agrée aussi la prononciation utilisée aux universités d'Oxford et de Cambridge mais ce n'est pas le point de vue de la majorité des orthoépistes. C'est pour cela que Walker offre des recommandations non seulement aux Irlandais et aux Écossais mais aussi aux Gallois; il est un peu moins prolifique sur les variétés typiquement

43. Walker, 1791, définit ce terme ainsi : « Not refined; rude, uncivil; gross; inelegant; unaccomplished by education; mean, vile. »

44. Boswell, 1980 [1791], p. 273. Il s'agit d'Alexandre Wedderburne Loughborough (1733-1805).

45. The Athenaeum, 1808, p. 79. Le chroniqueur rapporte les éléments suivants : «In the same year (1775) he visited Scotland, for the purpose of reading Lectures on Elocution at Edinburgh, where he had introductions to most of the literati, and where he not only met with great success, but received many polite and friendly attentions, which where repeated upon a second visit to that country. He ever after retained a marked partiality for the Scottish nation; not more for the civilities and hospitalities that he had personally experienced, than for the clearness of intellect, the spirit of inquiry, and the propriety of conduct, which he observed so generally to prevail among them: nor would he ever hear any illiberal reflections cast upon them by those who allow themselves to be tainted by national prejudice, without warmly expressing his dissent. "

46. Osborn, 1954, p. 17.

47. C'était une norme proposée dès 1589 par George Puttenham.

48. Jones, 2006, p. 133.

49. Beattie, 1788, p. 92 : «The language, therefore, of the most learned and polite persons in London, and the neighbouring Universities of Oxford and Cambridge, ought to be accounted the standard of the English tongue, especially in accent and pronunciation: syntax, spelling and idiom, having been ascertained by the practice of good authors, and the content of former age. » 
anglaises, prétextant un manque de place, il gratifie cependant le lecteur de recommandations pour certains locuteurs de Londres qu'il nomme « Cockneys ».

Mais revenons-en aux Écossais. Walker ne fait pas de simples recommandations : il propose des règles; sa discussion est d'ailleurs intitulée «Rules to be observed by the natives of Scotland for attaining a just Pronunciation of English ${ }^{50} »$. Cette formulation correspond tout à fait au goût de l'époque en matière linguistique : on se trouve ici en pleine apogée du mouvement de codification. L'orthoépiste commente la nature particulière de la prononciation écossaise et affirme :

That pronunciation which distinguishes the inhabitants of Scotland is of a very different kind from that of Ireland, and may be divided into the quantity, the quality and accentuation of the vowels ${ }^{51}$.

En ce qui concerne la quantité, l'orthoépiste souligne le fait que les Écossais prononcent les voyelles accentuées comme des voyelles longues. Ainsi « habit » est prononcé " haybit ». Il note aussi, le changement de qualité des voyelles; « bed » par exemple devient «bad». Par contre, il fait un commentaire très succinct sur l'accentuation de mot, son modèle de référence étant la poésie : "The accentuation, both in Scotland and Ireland [...] is so much the same as that of England, that I can scarecely ${ }^{52}$ recollect any words in which they differ ${ }^{53}$. "

Aux problèmes liés à la prononciation erronée des mots («mispronunciation of words »), Walker ajoute le problème de l'intonation qu'il nomme « tone of voice ${ }^{54}$ ». Il souligne que celle-ci est caractérisée par une utilisation fréquente de ce qu'il nomme "rising inflexion », pour immédiatement préciser en note qu'il s'agit plus exactement de " the rising circumflex » et renvoie le lecteur à son célèbre traité The Melody of Speaking Delineated ${ }^{55}$. Walker semble hésitant sur ces deux dernières questions. Il

50. Walker, 1791, p. xi; sur la page-titre la rubrique est annoncée de la manière suivante : « Rules to be observed by the Natives of Scotland, Ireland, and London, for avoiding their respective Peculiarities. » Si Walker tire une grande partie de ces remarques de Sheridan envers lequel il reconnaît sa dette, il y ajoute des remarques qui lui sont propres.

51. Walker, 1791, p. xi.

52. Walker utilise cette orthographe dans sa préface. Orthographe confirmée dans le corps de son dictionnaire.

53. Walker, 1791, p. xi.

54. Walker, 1791, p. xii.

55. Walker, 1787, p. 16. Dans cet ouvrage il définit les deux types d'intonation de cette manière: «The rising inflexion, is that upward turn of the voice we generally use at the comma, or in asking question, which begins with a verb. [...] The rising circumflex begins with the falling slide, and ends with the rising upon the same syllable. This inflexion may be exemplified by the drawling tone we 
recommande aux Écossais d'adopter «the falling inflexion ${ }^{56}$ », et aux professeurs d'élocution de prononcer les mots en utilisant une intonation descendante lorsqu'ils sont en présence d'élèves écossais. Il apparaît cependant qu'il existe un problème majeur à cette méthode, et qu'il ne soit pas lié aux locuteurs écossais : «But while the human voice remained unstudied, there is little expectation that this distinction of the slides should be applied to these useful purposes ${ }^{57}$. " Quel résultat pouvait-on espérer? Boswell discute un cas antérieur au dictionnaire de Walker, celui d'Alexander Wedderburne :

$[\ldots]$; and though it was too late in life for a Caledonian to acquire the genuine English cadence, yet so sucessful were Mr Wedderburne's intructors ${ }^{58}$, and his own unabating endeavours, that he got rid of the coarse part of his Scotch accent, retaining only as much of the "native wood-note wild", as to mark his country; which, if any Scotchman should affect to forget I should heartily despise him $^{59}$.

Sheridan le rejoint sur ce point en s'appuyant sur sa pratique de maître d'élocution. Il évoque même le cas de Lord Aylmoor qui lorsqu'il parlait « had not the least tincture of the Scottish intonation ${ }^{60} »$.

Pour Walker, il n'est question que de corriger et il répète à plusieurs reprises le verbe « to correct ». Il fait néanmoins, à la fin de la section consacrée aux locuteurs de la "province » le commentaire suivant :

Hence it is, that the vulgar pronunciation of London, though not half so erroneous as that of Scotland, Ireland, or any of the provinces, is, to a person of correct taste, a thousand times more offensive and disgusting ${ }^{61}$.

Doit-on voir dans cette position de Walker une réaction à celles de certains orthoépistes, et plus particulièrement celle, juste trois ans auparavant, de James Beattie qui ne s'offusque pas des prononciations provinciales :

give to some words spoken ironically, as the word Clodius, in Cicero's oration for Milo. » John Walker, The Melody of Speaking Delineated; or Elocution Taught by Music, Londres, impr. pour l'auteur.

56. Il définit la «falling inflexion » ainsi : «The falling inflexion is generally used at the colon and semicolon, and must necessarily be heard in the answer to the former question. » Il ajoute un dernier modèle qu'il appelle « falling circumflex » qu'il définit en ces mots : « The falling circumflex begins with the rising and ends with the falling slide. This inflexion may be exemplified by the pronunciation of the word sword, in Cato's reply to Decius. » Walker, 1787, p. 16.

57. Walker, 1791, p. xii.

58. Il s'agissait du rival de Walker, Thomas Sheridan (1719-1788) et de Charles Macklin (1697-

1797); faits rapportés pour l'année 1763. Boswell, [1791] 1980, p. 273.

59. Boswell, [1791] 1980, p. 274-275. Les faits relatés le sont pour l'année 1763.

60. Sheridan, 1780, p. 65.

61. Walker, 1791, p. xiv. 
From what has been said, we may learn, that, as every nation and province has a particular accent, and as no man can speak intelligibly without one, we ought not to take offence at the tones of a stranger, nor give him any ground to suspect, that we are displeased with, or even sensible of them. However disagreeable his accent may be to us, ours, it is likely, is equally so to him ${ }^{62}$.

\section{Conclusion}

En 1773 Monboddo relevait la difficulté posée à un locuteur par l'articulation de sons n’appartenant pas à sa propre langue :

Further, to shew ${ }^{63}$ the difficulty of pronunciation, the fact is most certain, that those who have been accustomed to speak all their lives cannot without the greatest labour and pains learn to pronounce sounds that they have not been accustomed to. Thus a Frenchman that has not been taught English early in his youth, can hardly ever learn to pronounce the aspirated $t$, that is, $t h$; and an Englishman cannot pronounce that aspirated $\mathrm{K}$, or $\kappa$ of the Greeks, which we in Scotland pronounce with greatest ease.

Au même moment, dans le cadre plus restreint de la prononciation de l'anglais, de nombreux orthoépistes reconnaissaient, tel Thomas Spence (1775) dans sa préface que :

The great difficulty of the English tongue lies in the pronunciation; an exactness in which, after all the pains they can take, is found to be unattainable, not only by foreigners, but provincials ${ }^{64}$.

Dès 1757 Buchanan avait rappelé que la prononciation des locuteurs écossais était décrite comme «that rough and uncough brogue which is so harsh and unpleasant to an English ear $^{65}$ ». Quelques lignes plus haut, il avait précisé que ces locuteurs n'avaient jusqu'alors joui d'aucun guide adéquat pour remédier à ce problème.

Des règles pour la prononciation correcte étaient considérées avant tout comme un enjeu social par une grande partie de la population qui aspirait à une meilleure éducation; dans le cas des locuteurs écossais, il s'agissait d'un enjeu non seulement social mais aussi culturel et politique.

62. Beattie, 1788, p. 91.

63. Avec cette orthographe dans l'original.

64. Thomas Spence, 1775, deuxième page de la préface non paginée. Sous le vocable « provincial » Spence incluait non seulement les Écossais, mais aussi tous les locuteurs dont la prononciation de l'anglais ne correspondait pas à celle définie par Puttenham.

65. Buchanan, 1757, p. xv. 
Quoi qu'il en soit, les orthoépistes des Lumières étaient convaincus qu'en utilisant leurs méthodes et leurs ouvrages (reflets, aussi, d'un enjeu purement commercial), les locuteurs écossais «may in short time pronounce as properly and intelligibly as if they had been born and bred in London ${ }^{66} »$.

\section{Bibliographie}

Angus William, A pronouncing Vocabulary of the English Language, Glasgow, impr. par D. Niven.

Anonyme, " Obituary of Distinguished Persons. Mr John Walker », The Athenaeum, vol. III, n 13,1808 , p. 77-84.

BeAL Joan G., "John Walker: Prescriptivist or Linguistic Innovator? », dans Marina Dosseda et Charles Jones (éds), Insights into Late Modern English, Bern, Peter Lang, 2003.

Beattie James, The Theory of Language, Londres, impr. pour A. Straham; T. Cadell dans le Strand, et W. Creech, Édimbourg.

Boswell James, Life of Fohnson. Unabridged, Oxford, Oxford University Press, World's Classics, 1980 [1791].

Buchanan James, Linguae Britannicae vera pronunciatio or a New English Dictionary, Londres, A. Millar, 1757.

Burn John, A Pronouncing Dictionary of the English Language, Glasgow, Alex. Adam pour l'auteur et James Duncan, 1786 [1777].

GÖRLACH Manfred, Eighteenth Century English, Heidelberg, Universitätsverlag C. Winter, 2001.

Johnson Samuel, A Dictionary of the English Language, Londres, W. Strahan pour J. \& P. Knapton, T. \& T. Longman et al., 1755.

Jones Charles (éd.), A Treatise on the Provincial Dialect of Scotland. Sylvester Douglas, Édimbourg, Edinburgh University Press, 1991.

Jones Charles, « Alexander Geddes: an Eighteenth Century Orthoepist and Dialectologist », Folia Linguistica Historica, vol. XV, n 1-2, 1994, p. 71-103.

—, English Pronunciation in the Eighteenth and Nineteenth Centuries, Houndsmill, Palgrave, 2006.

KenRIck William, A New Dictionary of the English Language, Londres, John et Francis Rivington, William Johnston et al., 1773.

Monboddo James, Burnett, Of the Origin and Progress of Language, Édimbourg, impr. pour A. Kincaid et W. Greech, Édimbourg et T. Cadell dans le Strand, Londres, vol. I, 1773.

66. Buchanan, 1757, p. xv. 
Mugglestone Lynda, 'Talking Proper' The Rise of Accent as Social Symbol, Oxford, Clarendon Press, 1997 [1995].

Osborn James Marshall, Dr. Fohnson and the Contrary Converts, New Haven, Yale University Press, 1954.

Percy Carol, « Consumers of Correctness. Men, Women, and Language in Eighteenth-Century Classified Advertisements », dans Christian Kay, Simon Horobin and Jeremy Smith (éds), New perspectives on English Historical Linguistics, Selected Papers from 12 ICHEL, Glasgow, 21-26 August 2002, Vol. I: Syntax and Morphology, Amsterdam, John Benjamins Publishing Company, 2004.

Perry William, Royal Standard English Dictionary, Édimbourg, impr. pour l'auteur par David Willison, 1775.

SheriDan Thomas, A General Dictionary of the English Language, Londres, R. \& J. Dodsley, C. Dilly, et J. Wilkie.

Simpson John et and Weiner Edmund S. C. (éds), The Oxford English Dictionary, $2^{\mathrm{c}}$ édition, vol. VIII, Oxford, Clarendon Press, 1991 [1989].

Spence Thomas, The Grand Repository of the English Language, Newcastle, T. Saint, 1775.

SwIFT Jonathan, A Proposal for Correcting, Improving and Ascertaining the English Tongue, Londres, Benjamin Tooke, 1712.

Walker John, The Melody of Speaking Delineated; or Elocution Taught by Music, Londres, impr. pour l'auteur, 1787.

—, A Critical Pronouncing Dictionary and Expositor of the English Language, Londres, G. G. J. et J. Robinson et T. Cadell, 1791. 